\author{
(c) (i) (8) \\ Journal of Education, Teaching and Learning is licensed under \\ a Creative Commons Attribution-Non Commercial 4.0 International License. \\ Syahrul Munir ${ }^{1)}$, Emzir ${ }^{2)}$, Aceng Rahmat ${ }^{3)}$ \\ ${ }^{1)}$ Universitas Negeri Jakarta, Jakarta, Indonesia \\ E-mail: syarulmunir160@gmail.com \\ ${ }^{2)}$ State University of Jakarta, Indonesia \\ E-mail:emzir.unj@gmail.com \\ ${ }^{3)}$ State University of Jakarta, Indonesia \\ E-mail:pbltppsunj@unj.ac.id
}

\title{
The Effect of Teaching Methods and Learning Styles on Students' English Achievement (An Experimental Study at Junior High School 1 Pasangkayu)
}

\begin{abstract}
The objectives of the research are to determine the effects of teaching methods (STAD and jigsaw) and learning styles (visual, auditory, and kinesthetic) on students' English achievement. This research is an experimental study conducted at Junior High School Pasangkayu in 2014 with 213 sample which is selected stratified-randomly $(n=68)$. The results of the research are as follow: (1) English achievement of students taught with STAD is better than those of taught with jigsaw; (2) there is no significant difference in English achievement among visual, auditory, and kinesthetic students; (3) there is any significant effect of interaction among teaching method and learning styles on students' learning English achievement. The research also find out that for visual students, studying English achievement of students taught with STAD is better than that of students taught with jigsaw; for auditory students, learning English achievement of students taught with jigsaw is better than that of students taught with STAD; and for kinesthetic students, English achievement of students taught with STAD is better than that of students taught with jigsaw. To sum up, STAD is more effective than jigsaw in improving students' English achievement. STAD is suitable to improve English achievement of visual and kinesthetic students, and jigsaw is suitable to improve English achievement of auditory students.
\end{abstract}

Keywords: STAD; Jigsaw; Visual Learning Style; Auditory Learning Style; Kinesthetic Learning Style; English Achievement

\section{INTRODUCTION}

The problems that arise in the world of education are a major obstacle to the development of education. One of the most vulnerable issues in the world of education today is the low level of student learning outcomes including student learning outcomes in English subjects.

English is important for students because it is an international language. That is not cover the fact that although English is important but most of the students do not like this subject for various reasons. This fact is clearly a challenge for teachers in choosing and using strategies, approaches, methods, and techniques that involve many students actively in learning and mentally, physically, and socially, that learners will be more creative if they involve them actively in the learning process as a whole.
English language learning in junior high school is targeted so that students are able to use it in oral and written communication so as to solve everyday problems. Through learning

English students are expected to have the ability to: (1) develop the competence of communicating in oral and written forms to achieve the level of functional literacy; (2) have an awareness of the nature and importance of English to improve the nation's competitiveness in a global society; (3) developing students' understanding of the interrelationship between language and culture (Puskur, 2014: 2-3). But the situation in the field has not been in accordance with the expected target. The results of the study indicate that although the improvement of educational quality is quite encouraging, but the learning and understanding of 
junior high school students (on some subject matter including English) showed less satisfactory results. English language learning in junior schools tends to be rote-oriented and. without the practice of use in communication (Musron, 2013: 19).

In junior high school (SMP), English is taught with a target so that students are able to use it in oral and written communication to solve daily problems so that students have abilities, among others, namely: (1) developing communication competence in the form of oral and writing to achieve the level of functional literacy; (2) have an awareness of the nature and importance of English to improve the nation's competitiveness in a global society; (3) developing students' understanding of the interrelationship between language and culture (Puskur, op.cit: 2-3).

In the practice of learning, English subjects in junior high school are taught in an integrated manner that includes receptive skills (listening and reading) and productive skills (speaking and writing). In the presentation of learning materials, a teacher can focus on more than one skill, for example, listening integrated with speaking or reading integrated with writing. Thus, the English language ability achieved by a student is a representation of the measurement results of the four types of language skills embodied in the form of values or scores.

The result of the observation showed that the learning of English in SMPN 1 Pasangkayu was still dominated by teacher (teacher-centered); the teacher explains the subject matter and the students listen to the explanation with attention, then the teacher gives examples of guided training questions, then proceed with giving practice to the students to taste individually. The learning process applied by the teacher can be categorized as a conventional learning method (direct learning). Through conventional learning methods that can expect the process of transfer of knowledge through the delivery of materials that are carried out effectively and efficiently by using time to learn in the classroom. Learning methods that emphasize student involvement actively (student-centered), for example in the form of cooperative learning: student teams achievement division STAD and jigsaw not yet fully used as one of alternative to improve student learning result. Should be in the process of daily learning a teacher can use varied learning methods that can improve student creativity. It can not be denied that through a cooperative learning process students can help each other with one group of friends and compete with other groups to make their group the best group. Therefore, if this approach is to be applied in the learning process, the principle of cooperation will be of greater benefit to the student and in turn, can improve the learning outcomes. Through STAD and jigsaw methods students can play an active role in learning activities. This strategy is a lot of growing learning activities as a supervisor of student activities. Student activeness in learning enables them to have better learning outcomes.

In addition to learning methods that are external factors that can affect learning outcomes, there are several other factors that can be expected to affect. These factors are internal factors within the student. So in designing learning, a teacher needs to consider these factors. One of the factors that teachers need to pay attention to, other than motivation, interests, attitudes, intelligence, talents, and a number of other innate attributes, is the learning style. Students in the classroom are groups that have a diversity of learning styles. Learning styles refer to consistent tendencies or likes as a general characteristic of the student's self, and that distinguishes them from other students in learning (Brown, 2007: 127) Educational psychologists have detailed the different types of learning styles individuals have with different titles and divide it into three main groups, namely learning styles of cognitive dimensions, learning styles of affective dimension, and learning styles of perceptual dimension. The learning style of the perceptual dimension, according to Hyland, is more relevant in learning English as a second language / foreign language (Hyland, 2006: 43). This perceptual learning style consists of visual learning styles, auditorial learning styles, and kinesthetic learning styles. Students who have visual learning styles have a tendency to see the picture of something as a whole, often affected by the style (appearance) of an object, attracted by color, layout, and design. Auditorial students tend to learn better through verbal explanations; for the visual student, the written word is no more meaningful than what he or she is listening to. While kinesthetic students tend to prefer learning by experiencing themselves; ideas and ideas will be more meaningful if they are practical, real, and relevant, and they need to do them in order to understand (Dobson, 2011: 34-35). Each individual with this type of learning style has its own way and preferences in learning.

Because each student has its own unique and unique learning style so that an absolute teacher is aware of this difference. However, teachers generally teach by the way they are taught. Many teachers, consciously or unconsciously, try to match or exceed the teacher who inspires them when they become 
students and choose methods that reflect the way they like to learn. As Kinsela said that without fundamental awareness, it is easy to believe that the way we learn is the most efficient way and ultimately biases the way we teach in the hope that students can learn the way we do (Kinsela, 2011: 190-194). DePorter says that if a teacher has a visual learning style he will tend to be a visual teacher too, and this happens naturally (DePorter, at al., 2009: 85-86). However, keep in mind that auditorial and kinesthetic students have a way of absorbing and processing information that is different from the visual student. Considering the diversity of students, the method of presenting the lesson should be varied and tailored to the characteristics of students who have different learning styles. Therefore, the way and method of teaching should vary and become an important consideration of teachers. According to Dobson that students will learn more effectively if it suits their preferred style and when learning materials and activities accommodate students' preference in learning, students will succeed (Dodson, 2011: 29).

Therefore, of the two types of cooperative learning methods (STAD and jigsaw), one of which may be more suitable for improving English learning outcomes, and possibly also each type of method is suitable for improving learning outcomes of English students with a particular learning style. So that the learning method (STAD and jigsaw) and perceptual dimension of learning style owned by students (visual, auditorial, and kinesthetic) are suspected to have an effect on to learning result of English. However, the extent to which these variables affect the learning outcomes of English still needs to be tested empirically. This research tries to reveal the influence of STAD and jigsaw learning method and perceptual dimension of learning style to English learning result in the hope that this research result can be one of alternative to improve the learning result of English. In addition, this study also tried to reveal the type of STAD and jigsaw methods that match the type of learning styles that each student has so that it can be considered to improve the learning outcomes of English.

Based on the above background, then the problem to be raised is how far the comparison of English learning outcomes in class VIII SMPN 1 Pasangkayu by using methods of student teams achievement division (STAD) and with jigsaw learning method in English subjects. Assuming that student teams achievement division (STAD) method is more beneficial than jigsaw learning method.

\section{RESEARCH METHOD}

This research is a $2 \times 3$ factorial experiment. The independent variable of research has two levels, namely (1) STAD method, and (2) jigsaw method. Attribute variables have three stages: (1) visual learning style; (2) auditorial learning style; and (3) kinesthetic learning styles. The affordable population of research is all students of class VIII SMP Negeri 1 Pasangkayu odd semester of academic year 2013/2014 consisting of 213 students. The sample of the study was 60 students, randomly stratified from the affordable population at $1 \%$ error level.

This means the level of generalization of research results generalization of $99 \%$. Referring to the Determination of the Sample Number of Populations developed by Isaac and Michael (in Sugiyono), the number of representative samples for population 68 is 60 . The sample is divided into three groups and based on the learning style questionnaire, 16 students are obtained for visual learning styles, 21 students for auditory learning styles and 31 students for kinesthetic learning styles. The steps of determining the study sample are presented in the following figure.

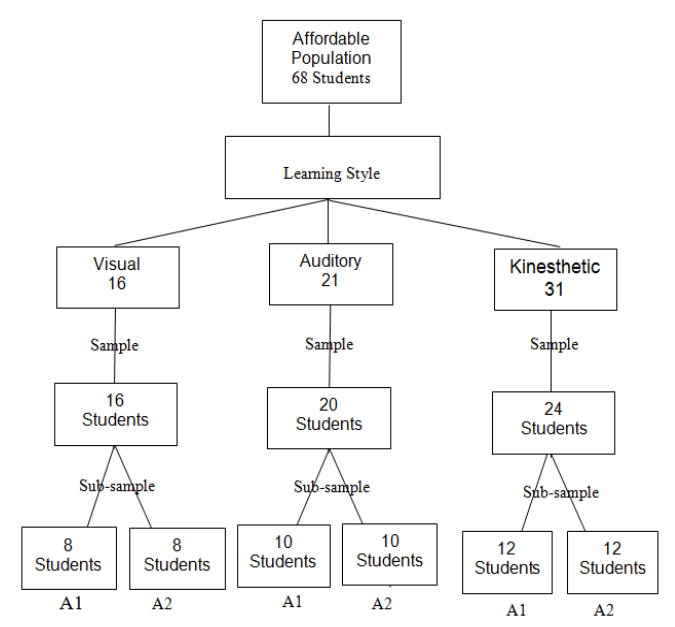

Fig. 1 Sample Determination Procedure Research

Based on the above figure it can be explained that the results of the questionnaire of learning styles given to the affordable population of the study showed that there were 16 students having visual learning styles, 21 students had auditory learning styles, and 31 students had kinesthetic learning styles. Furthermore, with reference to the number of preset samples and comparable sample grouping procedures in stratified sampling techniques, each identified learning style gained 16 $(100 \%)$ students for visual learning styles, 21 
students for auditory learning styles, and 31 students for kinesthetic learning styles.

The next step is to divide the sample of each type of learning style into a random sub-sample into two comparable groups. Each group contained 8 students each as a sub-sample of visual learning styles, each of 10 students as a sub-sample of auditory learning styles, and each of 12 students as sub-samples of kinesthetic learning styles. The two sub-samples of each type of learning style were each treated with different independent research variables. One group was taught by STAD and the other group was taught by jigsaw. The sample distribution tables in the experimental design are presented in the table below:

Table I

Distribution of Research Samples in Experimental Design Facts $2 \times 3$

\begin{tabular}{|c|c|c|c|c|}
\hline \multirow{2}{*}{\multicolumn{2}{|c|}{ Treatment Variables (A) }} & \multicolumn{2}{|c|}{$\begin{array}{l}\text { Method } \\
\text { (A) }\end{array}$} & \multirow[b]{2}{*}{ Total } \\
\hline & & $\begin{array}{c}\text { STAD } \\
\left(A_{1}\right)\end{array}$ & $\begin{array}{c}\text { Jigsaw } \\
\left(\mathrm{A}_{2}\right)\end{array}$ & \\
\hline \multirow{3}{*}{$\begin{array}{l}\text { Learning } \\
\text { Styles } \\
\text { (B) }\end{array}$} & Visual $\left(B_{1}\right)$ & 8 & 8 & 16 \\
\hline & Auditory $\left(B_{2}\right)$ & 10 & 10 & 20 \\
\hline & Kinesthetic $\left(B_{3}\right)$ & 12 & 12 & 24 \\
\hline \multicolumn{2}{|l|}{ Total } & 30 & 30 & 60 \\
\hline
\end{tabular}

Data were collected through instruments: (1) learning style questionnaire, and (2) English learning result test. Learning style instruments are developed based on the gratings made with reference to the theory and characteristics of perceptual learning styles. From 54 point statements for each type of learning style (visual, auditorial, and kinesthetic), after testing each instrument type can be used 48 valid items. The reliability coefficient for visual, auditorial, and kinesthetic learning style questionnaire was $0.978 ; 0.978$; and 0.977 as evidence of high instrument reliability. The coefficient of reliability of English learning result instruments tested through the reliability of ratings obtained by Alpha Cronbach price of 0.871 ; that is, the reliability of the test is quite high.

The data were analyzed by descriptive statistics and inferential statistics with the following steps: (1) descriptive analysis; (2) testing requirements analysis which includes normality test and homogeneity test; and (3) testing the research hypothesis using ANAVA $2 \times 3$ test and continued with Tukey test.

\section{RESULT AND DISCUSSION}

The result of the test of the main hypothesis $1 \mu \mathrm{A} 1=\mu \mathrm{A} 2$ obtained the value of F-count 11,551 exceed the F-table value (0.05: 1/144), 3,912 so there is evidence to reject $\mathrm{H} 0$ and receive $\mathrm{H} 1$ which means there is a significant difference between $\mu \mathrm{A} 1$ and $\mu \mathrm{A} 2$. Because $\mu \mathrm{A} 1>\mu \mathrm{A} 2(69,44>66,20)$ it can be concluded that the result of learning English students who are taught with STAD better than the result of learning English students who taught with jigsaw.

The result of hypothesis testing is $2 \mathrm{Ho}: \mu \mathrm{B} 1$ $=\mu \mathrm{B} 2=\mu \mathrm{B} 3$ the value of F-count 2,952 is less than F-table (0,05: 2/144) 3,063 so there is evidence to accept $\mathrm{Ho}$ and reject $\mathrm{H} 1$ which means there is no significant difference between $\mu \mathrm{B} 1 \quad(69,10), \mu \mathrm{B} 2$ $(68,10)$, and $\mu \mathrm{B} 3(66,28)$. So it can be concluded that there is no significant difference between the learning result of English for students who have visual, auditorial, and kinesthetic learning styles.

The result of hypothesis testing $3 \mathrm{H0}$ : A x B $=0$ obtained the value of F-count 27,109 exceed the value of F-table (0,05: 2/144), 3,063 so there is evidence to reject $\mathrm{H} 0$ and accept $\mathrm{H} 1: \mathrm{AXB} \neq 0$ which means there is influence in interaction between assigning tasks and learning styles to the ability to write English. So it can be concluded that the learning method (STAD and jigsaw) has a significant influence on English learning outcomes but the effect is different for each combination of treatments. Because there is an interaction effect between the variables studied, it is necessary to test the advanced hypothesis.

The result of hypothesis $4: \mu \mathrm{A} 1 \mathrm{~B} 1=\mu \mathrm{A} 2$ B1 obtained the value of Q-count of 7.524 over the Q-table value (0.05: 1/144) 3.92 so there is evidence to reject $\mathrm{H} 0$ and receive $\mathrm{H} 1$ which means there is a significant difference between $\mu \mathrm{A} 1 \mathrm{~B} 1$ and $\mu \mathrm{A} 2 \mathrm{~B} 1$. Because $\mu \mathrm{A} 1 \mathrm{~B} 1>\mu \mathrm{A} 2 \mathrm{~B} 1(73,48>64,68)$, it can be concluded that the ability to write English students visual assigned a holistic task is significantly better than those given a discrete task.

The result of hypothesis testing $5 \mathrm{H} 0: \mu \mathrm{A} 1$ $\mathrm{B} 2=\mu \mathrm{A} 2 \mathrm{~B} 2$ obtained value of Q-count 5,711 exceeded value of Q-table (0,05: 1/144) 3,92 so there is evidence to process $\mathrm{H} 0$ and receive $\mathrm{H} 1$ which mean there is significant difference between $\mu \mathrm{A} 1 \mathrm{~B} 2$ and $\mu \mathrm{A} 2 \mathrm{~B} 2$. Because $\mu \mathrm{A} 2 \mathrm{~B} 2>\mu \mathrm{A} 1 \mathrm{~B} 2 \quad(71,44 \mathrm{x}>$ $64,76)$ it can be concluded that the English writing ability of discretionary auditorial students is significantly better than those assigned holistic tasks.

Hypothesis 6 test results obtained Q-count value of 6.498 exceeded the value of Q-table $(0.05$ : 1/144) 3.92 so there is evidence to reject $\mathrm{HO}$ and receive $\mathrm{H} 1$ which means there is a significant difference between $\mu \mathrm{A} 1 \mathrm{~B} 3$ and $\mu \mathrm{A} 2 \mathrm{~B} 3$. Because $\mu \mathrm{A} 1 \mathrm{~B} 3>\mu \mathrm{A} 2 \mathrm{~B} 3(70,08>64,48)$ it can be concluded that the English writing ability of kinesthetic students 
given holistic tasks is significantly better than those assigned discrete tasks.

\section{CONCLUSIONS AND SUGGESTIONS}

Some research conclusions can be drawn: (1) STAD method is more effective than jigsaw method in improving English learning outcomes; (2) learning styles do not affect English learning outcomes; (3) STAD method is more suitable for improving learning outcomes of students' visual English and kinesthetic students; and (4) the jigsaw method, appropriate for improving English students' learning outcomes.

Suggestions that can be put forward are as follows: (1) because the learning outcomes of English can be improved by the use of appropriate learning methods it is important to present the learning materials using appropriate learning methods; (2) because every student has their own preference in learning, that there are some students who can only learn well if the learning materials are presented gradually from easy to difficult but there are students prefer the less difficult and challenging subject matter, so that in the practice of learning teachers need to provide more varied learning materials; (3) to developers and designers of English resource books, it is also advisable to design material materials that enable the use of varied methods.

\section{REFERENCES}

Ali, Mohamad. Konsep dan Penerapan CBSA (Cara Belajar Siswa Aktif) dalam Pengajaran. Bandung: Sarana Panca Karya, 2010.

Bandler, Richard. Effective Learning Techniques. Philadephia: Father \& Son, 2004.

Brown, H. Douglas. The Principles of Language Teaching and Learning. Boston: Pearson Education, 2007.

Buzan, Tony. Teaching and Learning. Oxford: Oxford University Press, 2007.

Dee, Amanda. Teacher Responsibilities.Illinois: Teacher Association, 2010.

DePorter, Bobbi \& Mike Hernacki, Quantum Learning: Membiasakan Belajar Nyaman dan Menyenangkan, terjemahan A. Abdurrahman. Bandung: Kaifa, 2007.

DePorter, Bobbi. Mark Reardon, dan Sarah Singer-Noure, Quantum Teaching, terjemahan Ary Nilandari. Bandung: Kaifa, 2009.

Diamond, Marian C. Teaching Methods, and Learning Difficulties. Los Angeles: Jeremy Publisher, 2009.

Dimyati, Mudjiano. Belajar dan Pembelajaran. Jakarta : Rineka Cipta, 2002.

Dobson, Graeme. A Guide to Writing Competency Based Training Materials. Melbourne: National Volunteer Skill Centre, 2011.

Dunn, Rita, Kenneth Dunn, dan Janet Perin, Teaching Your Children Through Their Learning Styles. Massachusetts: Alyn \& Bacon, 2010

Dörnyei, Zoltá. The Psychology of the Language Learner: Individual Differences in Second Language Acquisition.
London: Lawrence Erlbaum Associates Publishers, 2005.

Gie, Teh Liang. Cara Belajar Yang Baik. Yogyakarta : Gajah Mada University Press, 2007.

Griggs, S. A. Learning Styles Counseling. Washington, DC: ERIC Clearninghouse on Counseling and Personnel Service, 2009.

Hidayat, K. Evaluasi Pendidikan dan Penerapannya dalam Pengajaran Bahasa Indonesia. Bandung : Alfabeta, 2010.

Hyland, Ken. Second Language Writing. Cambridge: Cambridge University Press, 2005.

Keefe, J. W. Learning Styles: Theory and Practice. Boston: McBer and Company, 2010.

Kinsela, Kate."Understanding and Empowering Diverse Learners in ESL Classrooms," Learning Styles in ESL/EFL Classroom, ed. Joy M. Reid. New York: Heinle \& Heinle Publisher, 2011.

Kinsella, Kate. "Understanding and Empowering Diverse Learners in ESL Classrooms," Learning Styles in the ESL/EFL Classroom, ed. Joy M. Reid. New York: Heinle \& Heinle Publisher, 2011.

Kline, Peter. Effective Teaching and Learning. New York: Basic Books, 1999

Kroonenberg, N. Learning Styles, and Language Learning. New York: Harper and Row, 2009.

Leite, Walter, Marilla Svinicki; dan Yuing Shi, Attempted Validation of the Scores of VARK: Learning Styles Inventory with Multi Trait-Multimethod Confirmatory Factor Analysis Models. Boston: McBer and Company, 2009.

Lightbown, Patsy \& Nina Spada, How Languages are Learned. Oxford: Oxford University Press, 2008.

Margulie, Nancy. Teaching Media. Melbourne: University of Wollongong, 2002.

Melvin L. Silbeman, Active Learning: 101 Cara Belajar Aktif, terjemahan Raisul Muttaqien. Bandung: Nusamedia, 2009.

Mills, D. W. Applying What We Know: Students Learning Style. Los Angeles: Western Psychology Services, 2010.

Misbach, Ifa H. Dahsyatnya Sidik Jari: Menguak Bakat \& Potensi untuk Merancang Masa Depan Melalui Finger Print Analysis. Jakarta: Visimedia, 2010.

Oliver, Carolyn dan Rosemary F. Bowler, Learning to Learn. New York: Simon \& Schuster, 2006.

Learning to Learn. New York: Simon \& Schuster, 2008.

Rid, R. The Psychology of the Language Learners. Oxford: Oxford University Press, 1995.

Rodger, Nun. Teaching and Learning. New York: Dell Publishing, 2010.

Rose, Collin. Accelerated Learning. New Jersey: Prentice-Hall, 2007.

Silverman, Linda. "The Visual-Spatial Learner," Gifter Development Center, No. 8, Vol. 12, Dec. 2010.

Sinetar, Marsha. Teacher's Competency and Students' Performance. New Delhi: Great Ocean Publisher, 2010.

Snyder, Steve. Effective Teaching Methods. Canada: E. P. Dutton, 2005.

Sugiyono, Metode Penelitian Pendidikan. Bandung: Alfabeta, 2011.

Thomas F. Hawk dan Amit J. Shah, "Using Learning Style Instruments to Enhance Student Learning," Decision Sciences Journal of Innovative Education, Vol. 14. No. 29 , Oct. 2010. 